\title{
Front Matter: Volume 8654
}

, "Front Matter: Volume 8654," Proc. SPIE 8654, Visualization and Data Analysis 2013, 865401 (4 February 2013); doi: 10.1117/12.2020820

SDIE Event: IS\&T/SPIE Electronic Imaging, 2013, Burlingame, California, United SPIE. States 


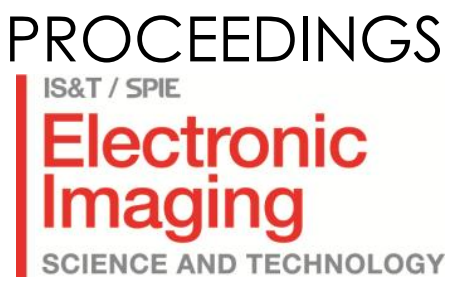

\section{Visualization and Data Analysis 2013}

Pak Chung Wong

David L. Kao

Ming C. Hao

Chaomei Chen

Editors

4-6 February 2013

Burlingame, California, United States

Sponsored and Published by

IS\&T-The Society for Imaging Science and Technology

SPIE

Cosponsored by

Kitware Inc. (United States)

Visual Analytics Community (United States)

Hewlett-Packard Company (United States) 
The papers included in this volume were part of the technical conference cited on the cover and title page. Papers were selected and subject to review by the editors and conference program committee. Some conference presentations may not be available for publication. The papers published in these proceedings reflect the work and thoughts of the authors and are published herein as submitted. The publishers are not responsible for the validity of the information or for any outcomes resulting from reliance thereon.

Please use the following format to cite material from this book:

Author(s), "Title of Paper," in Visualization and Data Analysis 2013, edited by Pak Chung Wong, David L. Kao, Ming C. Hao, Chaomei Chen, Proceedings of SPIE-IS\&T Electronic Imaging, SPIE Vol. 8654. Article CID Number (2013)

ISSN: 0277-786X

ISBN: 9780819494276

Copublished by

SPIE

P.O. Box 10, Bellingham, Washington 98227-0010 USA

Telephone +1 3606763290 (Pacific Time) · Fax +1 3606471445

SPIE.org

and

IS\&T-The Society for Imaging Science and Technology

7003 Kilworth Lane, Springfield, Virginia, 22151 USA

Telephone +1 7036429090 (Eastern Time) · Fax +1 7036429094

imaging.org

Copyright (c) 2013, Society of Photo-Optical Instrumentation Engineers and The Society for Imaging Science and Technology.

Copying of material in this book for internal or personal use, or for the internal or personal use of specific clients, beyond the fair use provisions granted by the U.S. Copyright Law is authorized by the publishers subject to payment of copying fees. The Transactional Reporting Service base fee for this volume is $\$ 18.00$ per article (or portion thereof), which should be paid directly to the Copyright Clearance Center (CCC), 222 Rosewood Drive, Danvers, MA 01923. Payment may also be made electronically through CCC Online at copyright.com. Other copying for republication, resale, advertising or promotion, or any form of systematic or multiple reproduction of any material in this book is prohibited except with permission in writing from the publisher. The CCC fee code is 0277-786X/13/\$18.00.

Printed in the United States of America.

Paper Numbering: Proceedings of SPIE follow an e-First publication model, with papers published first online and then in print and on CD-ROM. Papers are published as they are submitted and meet publication criteria. A unique, consistent, permanent citation identifier (CID) number is assigned to each article at the time of the first publication. Utilization of CIDs allows articles to be fully citable as soon as they are published online, and connects the same identifier to all online, print, and electronic versions of the publication. SPIE uses a six-digit CID article numbering system in which:

- The first four digits correspond to the SPIE volume number.

- The last two digits indicate publication order within the volume using a Base 36 numbering

system employing both numerals and letters. These two-number sets start with 00, 01, 02, 03, 04, $05,06,07,08,09,0 A, 0 B \ldots$. OZ, followed by 10-1Z, 20-2Z, etc.

The CID Number appears on each page of the manuscript. The complete citation is used on the first page, and an abbreviated version on subsequent pages. Numbers in the index correspond to the last two digits of the six-digit CID Number. 


\section{Contents}

vii Conference Committee

ix Introduction

\section{HIGH DIMENSIONAL AND MULTI-FOCUS VISUALIZATION}

865402 An interactive visual testbed system for dimension reduction and clustering of large-scale high-dimensional data [8654-1]

J. Choo, H. Lee, Z. Liu, J. Stasko, H. Park, Georgia Institute of Technology (United States)

865403 Multi-focus and multi-level techniques for visualization and analysis of networks with thematic data [8654-2]

M. Cossalter, O. J. Mengshoel, T. Selker, Carnegie Mellon Silicon Valley (United States)

\section{MULTIVARIATE TIME SERIES}

865404 Visual analytics of cyber physical data streams using spatio-temporal radial pixel visualization [8654-3]

M. Hao, M. Marwah, Hewlett-Packard Labs. (United States); S. Mittelstaedt, H. Janetzko, D. Keim, Univ. Konstanz (Germany); U. Dayal, C. Bash, C. Felix, C. Patel, M. Hsu, Y. Chen, Hewlett-Packard Labs. (United States); M. Hund, Univ. Konstanz (Germany)

865405 Exploring large scale time-series data using nested timelines [8654-4]

Z. Xie, Oracle America Inc. (United States); M. O. Ward, E. A. Rundensteiner, Worcester Polytechnic Institute (United States)

\section{FLOW AND VOLUME VISUALIZATION}

865406 Visibility-difference entropy for automatic transfer function generation (Best Student Paper) [8654-5]

P. Schlegel, R. Pajarola, Univ. of Zürich (Switzerland)

865407 Coherent view-dependent streamline selection for importance-driven flow visualization [8654-6]

J. Ma, C. Wang, C.-K. Shene, Michigan Technological Univ. (United States)

865408 Single-pass GPU-raycasting for structured adaptive mesh refinement data [8654-7]

R. Kaehler, T. Abel, SLAC National Accelerator Lab. (United States) 
HIGH PERFORMANCE COMPUTING

865409 Multi-user smartphone-based interaction with large high-resolution displays [8654-8]

L. Nguyen, J. P. Schulze, Univ. of California, San Diego (United States)

8654 OA Stereo frame decomposition for error-constrained remote visualization [8654-9]

S. Martin, H.-W. Shen, The Ohio State Univ. (United States)

\section{KEYNOTE SESSION I}

8654 OB Why high performance visual data analytics is both relevant and difficult (Keynote Presentation) [8654-10]

E. W. Bethel, P. Prabhat, S. Byna, O. Rübel, K. J. Wu, M. Wehner, Lawrence Berkeley National Lab. (United States)

\section{BIOMEDICAL VISUALIZATION}

8654 0C Three-dimensional volume analysis of vasculature in engineered tissues (Best Student Paper) [8654-11]

M. YousefHussien, Rochester Institute of Technology (United States); K. Garvin, D. Dalecki, Univ. of Rochester (United States); E. Saber, M. Helguera, Rochester Institute of Technology (United States)

8654 OD 3D surface reconstruction and visualization of the Drosophila wing imaginal disc at cellular resolution [8654-12]

L. Bai, Drexel Univ. (United States); T. Widmann, Centro de Genómica e Investigación Oncológica (Spain); F. Jülicher, Max-Planck-Institut für Physik komplexer Systeme (Germany); C. Dahmann, Dresden Univ. of Technology (Germany); D. Breen, Drexel Univ. (United States)

HUMAN FACTORS

8654 OE Visual exploration and analysis of human-robot interaction rules [8654-13]

H. Zhang, M. J. Boyles, Indiana Univ. (United States)

8654 OF Emotion scents: a method of representing user emotions on GUI widgets [8654-14]

D. Cernea, Technische Univ. Kaiserslautern (Germany) and Linnaeus Univ. (Sweden);

C. Weber, A. Ebert, Technische Univ. Kaiserslautern (Germany); A. Kerren, Linnaeus Univ. (Sweden)

\section{EXPLORATORY DATA ANALYSIS}

8654 OG Visual analysis of situationally aware building evacuations (Best Student Paper) [8654-15] J. Guest, T. Eaglin, K. Subramanian, W. Ribarsky, The Univ. of North Carolina at Charlotte (United States) 
$8654 \mathrm{OH} \quad$ Improving projection-based data analysis by feature space transformations [8654-16] M. Schaefer, L. Zhang, T. Schreck, A. Tatu, Univ. Konstanz (Germany); J. A. Lee,

M. Verleysen, Univ. Catholique de Louvain (Belgium); D. A. Keim, Univ. Konstanz (Germany)

8654 0l Does interactive animation control improve exploratory data analysis of animated trend visualization? [8654-17]

F. A. Abukhodair, Simon Fraser Univ. (Canada) and King Abdulaziz Univ. (Saudi Arabia);

B. E. Riecke, H. I. Erhan, C. D. Shaw, Simon Fraser Univ. (Canada)

\section{DATA ANALYSIS TECHNIQUES}

8654 OK iMap: a stable layout for navigating large image collections with embedded search (Best Paper) [8654-19]

C. Wang, J. P. Reese, H. Zhang, J. Tao, R. J. Nemiroff, Michigan Technological Univ. (United States)

8654 OL UVis Studio: an integrated development environment for visualization [8654-21]

K. Pantazos, M. A. Kuhail, S. Lauesen, S. Xu, The IT Univ. of Copenhagen (Denmark)

\section{INTERACTIVE TECHNIQUES}

8654 OM Interactive visual comparison of multimedia data through type-specific views [8654-22]

R. Burtner, S. Bohn, D. Payne, Pacific Northwest National Lab. (United States)

$8654 \mathrm{ON}$ Evaluating multivariate visualizations on time-varying data [8654-23]

M. A. Livingston, J. W. Decker, Z. Ai, U.S. Naval Research Lab. (United States)

865400 Multi-focus and multi-window techniques for interactive network exploration (Best Student Paper) [8654-24]

P. K. Sundarararajan, O. J. Mengshoel, T. Selker, Carnegie Mellon Silicon Valley (United States)

\section{INTERACTIVE PAPER SESSION}

8654 OP Effective color combinations in isosurface visualization [8654-25]

S. Einakian, T. S. Newman, The Univ. of Alabama in Huntsville (United States)

$8654 \mathrm{OQ}$ Web tools for rapid experimental visualization prototyping [8654-26]

J. W. Decker, M. A. Livingston, U.S. Naval Research Lab. (United States)

8654 OR Time-based user-movement pattern analysis from location-based social network data [8654-27]

H. L. Chuan, I. Kulkumjon, S. Dangi, Carnegie Mellon Silicon Valley (United States)

8654 OS Visualizing vascular structures in virtual environments [8654-28]

T. Wischgoll, Wright State Univ. (United States) 
8654 OT A combined multidimensional scaling and hierarchical clustering view for the exploratory analysis of multidimensional data [8654-29]

P. Craig, Univ. Technológica de la Mixteca (Mexico); N. Roa-Seïler, Univ. Technológica de la Mixteca (Mexico) and Napier Univ. (United Kingdom)

8654 OU Visualization of decision processes using a cognitive architecture [8654-30] M. A. Livingston, A. Murugesan, D. Brock, W. K. Frost, D. Perzanowski, U.S. Naval Research Lab. (United States)

8654 OV Vortex core timelines and ribbon summarizations: flow summarization over time and simulation ensembles [8654-31]

A. Y. L. Chan, J. Lee, R. M. Taylor II, The Univ. of North Carolina at Chapel Hill (United States)

8654 OW X3DBio2: A visual analysis tool for biomolecular structure comparison [8654-32]

H. Yi, S. Thakur, Renaissance Computing Institute (United States); L. Sethaphong,

Y. G. Yingling, North Carolina State Univ. (United States)

8654 OX Improvement of web-based data acquisition and management system for GOSAT validation lidar data analysis [8654-33]

H. Okumura, S. Takubo, T. Kawasaki, I. N. Abdullah, Saga Univ. (Japan); O. Uchino, I. Morino, T. Yokota, National Institute for Environmental Studies (Japan); T. Nagai, T. Sakai, T. Maki, Meteorological Research Institute (Japan); K. Arai, Saga Univ. (Japan)

8654 OY Optimizing threshold for extreme scale analysis [8654-35]

R. Maynard, Kitware, Inc. (United States); K. Moreland, Sandia National Labs. (United States); U. Atyachit, B. Geveci, Kitware, Inc. (United States); K.-L. Ma, Univ. of California, Davis (United States)

$86540 Z$ Perceptualization of geometry using intelligent haptic and visual sensing [8654-36] J. Weng, Zhejiang Univ. of Media and Communications (China); H. Zhang, Indiana Univ. (United States)

865410 Review of chart recognition in document images [8654-37]

Y. Liu, Peking Univ. (China), Peking Univ. Founder Group Co., Ltd. (China), and Zhongguancun Haidian Science Park (China); X. LU, Y. Qin, Z. Tang, Peking Univ. (China); J. Xu, Peking Univ. Founder Group Co., Ltd. (China)

Author Index 


\section{Conference Committee}

Symposium Chairs

Gaurav Sharma, University of Rochester (United States)

Sergio R. Goma, Qualcomm Inc. (United States)

Conference Chairs

Pak Chung Wong, Pacific Northwest National Laboratory (United States)

David L. Kao, NASA Ames Research Center (United States)

Ming C. Hao, Hewlett-Packard Laboratories (United States)

Chaomei Chen, Drexel University (United States)

Conference CoChairs

Christopher G. Healey, North Carolina State University (United States) Mark A. Livingston, U.S. Naval Research Laboratory (United States) Ian Roberts, Pacific Northwest National Laboratory (United States) Thomas Wischgoll, Wright State University (United States)

Conference Program Committee

Madjid Allili, Bishop's University (Canada)

Barry Becker, PROS Holdings, Inc. (United States)

Remco Chang, Tufts University (United States)

Guoning Chen, The University of Utah (United States)

Yi-Jen Chiang, Polytechnic Institute of New York University (United States)

George Chin Jr., Pacific Northwest National Laboratory (United States)

Jaegul Choo, Georgia Institute of Technology (United States)

Scott E. Dillard, Pacific Northwest National Laboratory (United States)

Sussan Einakian, The University of Alabama in Huntsville (United States)

John Gerth, Stanford University (United States)

Matti T. Gröhn, Finnish Institute of Occupational Health (Finland)

Halldor Janetzko, Universität Konstanz (Germany)

Ming Jiang, Lawrence Livermore National Laboratory (United States)

Alark Joshi, Boise State University (United States)

Daniel F. Keefe, University of Minnesota, Twin Cities (United States)

Andreas Kerren, Linnaeus University (Sweden)

Robert R. Lewis, Washington State University (United States)

Guo-Shi Li, ExxonMobil Upstream Research Company (United States) 
Peter Lindstrom, Lawrence Livermore National Laboratory (United States)

Lars Linsen, Jacobs Universität Bremen gGmbH (Germany)

Zhanping Liu, Kentucky State University (United States)

Aidong Lu, The University of North Carolina at Charlotte (United States)

Thomas Malzbender, Hewlett-Packard Laboratories (United States)

Richard May, Pacific Northwest National Laboratory (United States)

Joerg Meyer, Lawrence Berkeley National Laboratory (United States)

Harald Obermaier, University of California, Davis (United States)

Donald A. Pellegrino, The Dow Chemical Company (United States)

Theresa-Marie Rhyne, Consultant (United States)

René Rosenbaum, University of California, Davis (United States)

Tobias Schreck, Universität Konstanz (Germany)

Anna Shaverdian, University of Michigan (United States)

Chad A. Steed, Oak Ridge National Laboratory (United States)

Kalpathi R. Subramanian, The University of North Carolina at Charlotte (United States)

Shigeo Takahashi, The University of Tokyo (Japan)

Soon Tee Teoh, San José State University (United States)

Chaoli Wang, Michigan Technological University (United States)

Gunther Weber, Lawrence Berkeley National Laboratory (United States)

Yingcai Wu, University of California, Davis (United States)

Jing Yang, The University of North Carolina at Charlotte (United States)

Caixia Zhang, Google (United States)

Jian Zhang, IBM China Research Laboratory (China)

Song Zhang, Mississippi State University (United States)

Caroline Ziemkiewicz, Brown University (United States) 


\section{Introduction}

\section{Celebrating 20 Years of Community Participation at SPIE Conference on Visualization and Data Analysis 2013}

Welcome to the SPIE Conference on Visualization and Data Analysis (VDA) 2013. This year we proudly celebrate the $20^{\text {th }}$ anniversary of the VDA conference that supports the international community of visualization and data analysis. VDA 2013 will be held in the city of Burlingame near San Francisco, CA on February 4-6, 2013.

VDA 2013 is organized by a team of chairs (Pak Chung Wong, David Kao, Ming Hao, and Chaomei Chen) and co-chairs (Mark Livingston, Christopher Healey, Thomas Wischgoll, and lan Roberts). David Kao and Ming Hao also serve as the paper chairs and Chaomei Chen as the best paper chair. Ian Roberts designs and maintains the VDA conference website at http://vda-conference.org. The entire conference committee supports all aspects of conference organizing activities including paper review, publicity and sponsorship development, and keynote speaker invitation.

This year, the conference received 36 high-quality manuscript submissions from the visualization and data analysis community from around the world. Each submission received at least three peer reviews. The two paper chairs examined the reviewers' comments and selected 21 manuscripts as full papers for conference presentation. The best paper chair independently selected five best conference papers from the accepted full papers. Authors of the best papers are invited to extend their VDA manuscripts for potential publication in Information Visualization (IVI) in 2013. Lead student authors of the best papers will also receive a modest monetary award from the VDA conference. The best papers at VDA 2013 are:

1. [8654-5] Visibility-difference entropy for automatic transfer function generation - Student Paper

2. [8654-11] Three-dimensional volume analysis of vasculature in engineered tissues - Student Paper

3. [8654-15] Visual analysis of situationally aware building evacuations Student Paper

4. [8654-19] iMap: a stable layout for navigating large image collections with embedded search - Paper

5. [8654-24] Multi-focus and multi-level techniques for interactive network exploration - Student Paper 
The conference also accepted 12 poster papers for interactive presentation on Wednesday during the conference week.

Two renowned visualization and data analysis researchers will deliver their keynotes addresses at VDA 2013. Dr. Wes Bethel of Lawrence Berkeley National Laboratory will present on Monday, and Dr. Meichun Hsu of HP Labs will present on Tuesday. Their presentations will cover both the scientific and information aspects of visualization and data analysis areas.

VDA 2013 has received corporate sponsorships from (in alphabetical order) HP Labs, Kitware, SPIE, and VA Community. Their financial support allows the conference to maintain the conference website, offer four best student paper awards in 2013, and host the annual dinner party for all paper authors, presenters, and conference organizers on Monday evening during the conference week. We gratefully appreciate the continued support of the VDA conference sponsors.

We thank the paper and poster authors, program committee members, and paper reviewers, who continue to support the VDA conference. We also thank the staff at SPIE, who patiently and effectively supports VDA throughout the year. We encourage all VDA participants to share their conference improvement ideas and thoughts with the conference chairs. Finally, on behalf of the entire conference organizing committee, we look forward to serving the VDA community and the SPIE society for another 20 years.

Pak Chung Wong
David L. Kao
Ming C. Hao
Chaomei Chen 